\title{
GÖRSEL BİR İMAJ VE MEKÂN METAFORUNUN KAYNAĞI OLARAK BAHAR
}

Mustafa Uğur KARADENİZ1

Atıf/ (O: Karadeniz, M., U. (2021). Görsel bir imaj ve mekân metaforunun kaynağ1 olarak bahar. Hitit Sosyal Bilimler Dergisi, 14(1), 232-243. doi: 10.17218/hititsbd.957364

Özet: Yaygın kullanımında bir mevsime karşılık gelen bahar sözcüğü, klâsik Türk şiirinde çiçek, yaprak, yüz ve yanak anlamlarının yanı sıra put, tapınak ve kiliseyi de karşılamaktadır. Sözcügün bu çok çeşitli kullanımlarında görsel bir tasviri ifade arayışı göze çarpmaktadır. Klâsik Türk şiirinde güzellik unsurlarının bir mekân estetiğinin yansımalarından doğduğu söylenebilir. Baharın lügatlerdeki karşılığına ve örnek metinlerde kullanımına bakıldığında, sözcüğün aslında mekânı ifade eden bir kavramken zamanla o mekânın niteliklerine benzer özellikler gösteren başka bir anlamsal forma dönüştüğü görülecektir. Hristiyanlara ait mabetlerde de tapınaklarda olduğu gibi resim ve putların bulunması, kilisenin klâsik Türk edebiyatında bahar sözcügüyle karşılanmasına neden olmuştur, denebilir. Şiirlerde görsel bir imaj öne çıkarılmak istendiğinde kilisenin (deyr), sahip olduğu resim ve süslemeler sebebiyle bir istiare olarak dış mekânın ifadesinde kullanıldığı görülmektedir.

Anahtar Kelimeler: Bahar, Mekân, Klâsik Türk Şiiri, Tapınak, Kilise

\section{Bahâr as a Source of Visual Image and Space Metaphor}

Citation/ (O: Karadeniz, M., U. (2021). Bahâr as a source of visual image and space metaphor. Hitit Journal of Social Sciences, 14(1), 232-243. doi: 10.17218/hititsbd.957364

Abstract: The word "bahâr" (spring), which corresponds to a season in its widespread use, corresponds to the meanings of flowers, leaves, faces, and cheeks in classical Turkish poetry, as well as put, temple, and church. The quest to express a visual depiction is conspicuous in this wide variety of uses of the word. It can be said that the elements of beauty in classical Turkish poetry arise from the reflections of a space aesthetic. When we look at the equivalent of "bahâr" in the lexicon and its use in sample texts, it will be seen that the word is actually a concept expressing the place, but gradually transformed into another semantic form that shows similar features to the qualities of that place. It can be said that the presence of pictures and idols in churches as in temples caused these places to be expressed with the word spring in classical Turkish literature. When a visual image is desired to be highlighted in poems, it is seen that the church (deyr) is used as a metaphor for the expression of the outer space due to the pictures and decorations it has.

Keywords: Bahar (Spring), Place, Classical Turkish Poetry, Temple, Church

\section{GİṘŞ}

Klâsik Türk şiirinde üzerinde en çok durulan mevsim, bahardır. Güzellik imajlarının kaynağının bahçe metaforuna dayandığı bu şiir geleneğini, bir bahar methiyesi olarak görmek bu açıdan yanlış sayılmamalıdır. Sevgilinin güzelliğini ortaya koymak için sürekli çiçek ve bitki stilizasyonu ile yapılan tasviri, şiirin ifade evreninde bu mevsimi vazgeçilmez kılmaktadır. Türk şiir ikliminde bahçe, güzellik ülkesinin asitanesidir. Bu asitanede tahta kurulan sevgili, kurduğu güzellik ordusuna en seçkin askerlerini daima çiçek ve ağaçlardan seçmiştir. 
Baharın bir diriliş yeniden doğuş mevsimi olması, ona kolaylıkla metafizik anlamlar yüklenmesini sağlamıştır. Diriliş ve doğuş, metafizik çağrışımlarla içinde yer aldıkları bağlamı dönüştürme gücüne sahip iki etkili kavramdır. Baharın metafizik bir etki uyandırması onun bu özelliği ile ilgili olmalıdır. Tabiatın uyanıp yeniden canlandığı bu mevsimin özlenen cennetin kısa bir vuslatı olmasının da bunda etkili olduğu açıktır. Sevgilinin tabiattan alınmış bilindik unsurlarla tasviri, bir aşinalık ve güven hissi oluşturur, cennetin de klâsik Türk şiirinin en önemli kaynaklarından biri olan Kur'an-1 Kerim'de bu dünyadaki bahçe unsurlarıyla² tasviri benzer şekilde bu hissi pekiştirir. Cennetin Arapçada bahçe anlamında olması ve yine onun tasvirlerde sürekli bahar mevsimindeki bir bahçe olarak görünmesi, baharla ilişkisini artırmakta, bütün bunlar bahara bir cennet hayali olarak bakılmasını kolaylaştırmaktadır. Cennetin metaforik etkisi sadece anlam düzeyinde kalmamış eser formlarına da sirayet etmiştir. Kendisinden sonra biçim olarak birçok esere ilham kaynağı olan Molla Câmi'ye ait Bahâristân isimli didaktik eserin taksiminin sekiz ravzaya (cennet bahçesi) ayrılması bu anlamda dikkat çekicidir. Cennet bahçelerinin de sayısı sekizdir. Yine klâsik Türk edebiyatında ilk tezkirelerin tedvin düzeninde de sekiz bölüme taksim etme anlayışının örneklerini görmek mümkündür.

Klâsik Türk şiirinde güzellik unsurları 1şığını, bir mekân estetiğinin yansımalarından alır. Güzele dair övgüler, güzel bir mekânın tasvirinden izler taşır. Sevgilinin ihtişam ve şaşası "saray istiaresi"nden gelmekle birlikte ona dair görsel imajlar kaynağını, estetik bir mekân olarak bahçenin tasvirinden almıştır, denebilir. Bu yüzden herhangi bir mekânın övgüsü yapılırken tıpkı sevgilinin methinde olduğu gibi aynı unsurlar rahatlıkla tekrar kullanılabilmiştir. Mekân bir güzellik formu olarak öne çıkmakla birlikte zamanla metaforlaşarak ondan doğan bazı kavramların kaynağının unutulmasına da neden olmuştur. Baharın da kaynağı unutulan bu kavramlardan biri olduğunu söylemek yanlış olmayacaktır. Lügatlerdeki karşılığına ve örnek metinlerde kullanımına bakıldığında, sözcüğün aslında mekânı ifade eden bir kavramken zamanla o mekânın niteliklerine benzer özellikler gösteren başka bir anlamsal forma dönüştüğü görülecektir.

İnsan zihnindeki sınırsız imajların sınırlı sayıdaki sözcüklerle ifadesi ister istemez sözcüklerde lafız ve mana ayrımını doğurmakta ve bu yüzden lafız sabit olmakla birlikte mananın sürekli değissip zenginleştiği bilinmektedir. Bu durum aynı lafzın birden fazla manaya, imaja karşılık olarak kullanımını da zorunlu kılmaktadır. Klâsik Türk şiirinde metin tanıklıklarından hareketle bahar sözcüğünün çok çeşitli anlamları içermekte olduğu ve şairlerin sözcüğün bu geniş anlam evreninden faydalandığı bu metinleri okuyanların zihninde canlanacaktır. Kelime yaygın olan mevsim anlamının dışında gül çeşitleri için de kullanılmaktadır. Ayrıca çiçek yapraklarına bahar denildiği gibi o, bizatihi çiçek ve yüz/yanak anlamlarını da karşılar. Yine kaynaklarda put ${ }^{3} /$ sanem $^{2}$ için de bazen bahar lafzının tercih edildiği yer almaktadır. Bunların dışında bahar, şiirlerde doğrudan olmasa bile bir işaret yoluyla varlığını sürdürerek bir mekânın adı olma niteliğine sahiptir. Bu çalışma da bahar/nev-bahar sözcüğünün bir tapınağın adı olmasına odaklanmıştır. Sözcük bu anlamından doğan çağrışımlarla şiirde güzellik imajlarına kaynaklık etmiş, bahar mevsimi anlamıyla da bu imajın görsel unsurlarının oluşmasına katkı sağlamıştır.

\section{BAHÂR SÖZCÜĞÜNÜN ANLAM ÇERÇEVESİ}

Bahar sözlüklerde çok zengin bir anlam evrenine sahip bir sözcük olarak ifade edilir. Farsça kökenli olduğu iddia edilmekle birlikte "bahâr"1n, Sanskritçede "vihara” sözcüğünden geldiği de

\footnotetext{
2 Kur’an'da yapılan cennet tasvirlerinde bu unsurları görmek mümkündür: "İkisi de yemyeşil. (...) İkisinde de gürül gürül akan iki su kaynağı bulunur. (...) Her ikisinde türlü meyveler, hurma ve nar var.” (Rahmân55/64-68)

3 Türkçede put olarak kullanılan sözcüğün aslı Farsça büttür. O da Buddha ismine dayanmaktadır (Güç, 2007).
} 
belirtilir. Sözcüğün ayrıca Farsçaya vihara kökünden dönüşerek "ferhâr"4 olarak geçtiği de kaynaklarda yer alır: "Bir put hane adıdır. Ferhâr kelimesi Sanskritçe Vihara kelimesinden muharref olup Budizm dinine sâlik olanların mabedi demekmiş. Bu dinlerin mabetlerinde birçok nukûş ve tesâvir bulunduğundan büt-i Ferhâr tabiri bu mabetlerdeki resimlere, heykellere benzetilmek suretiyle güzellere alem olmuş" (Onay, 2009, s.195).

Kilisenin tapınaklara benzer biçimde içerisinde resim ve putlar barındırması nedeniyle olmalı ki klâsik Türk edebiyatında bahar sözcüğüyle de karşılandığı görülmektedir. Âşı Çelebi tezkiresinde baharın, kilise anlamında kullanılmasına Bahârî mahlaslı şaire dair bir latifeyle dikkat çeker: "Adı 'Alî'dür. Evvel mahlası Kemâlî idi. Yârân Kem 'Alî diyü latîfe iderdi. Andan geçüp Bahârî tahallüs idindi. Bu kerre yârân ‘bahâr kilisaya dirler! Ne kâfirâne mahlasun var!' diyü sakîfe iderdi.” (Kılıç, 2018, s.187). Sözcüğün kilise yahut tapınak anlamının oldukça maruf olduğu, şaire dostlarının yaptığı bu latifeyle anlaşılmaktadır.

Ferheng-i Şu'ûrî'de bahar sözcüğünün on dört anlamı olduğu kayıtlıdır. Lügatte mevsim, yaprak (henüz çıkmış yaprak: nev-bahâr) gibi anlamlarına ek olarak tapınak anlamında bir bütgedeye de "bahâr" denildiği hususen aktarılır ve Fars edebiyatından sözcüğün bu anlamını içeren çeşitli şiir örnekleri verilir: "Bahar rüzgârının esmesiyle ilkbahar mevsimi geldi. Bahçeler kilise [bahar] gibi süslendi." Lügatin müellifi Şu'ûrî Hasan Efendi'nin de sözcüğün put/put hane anlamları üzerinde durduğu aktardığı metin örneklerinden anlaşılmaktadır. Müellif, "Büthâneye 'bahâr' denildiği üstâd Ferruhî'nin bu beytinde vâzıhtır." diyerek lafzen baharın kilise/tapınak anlamında kullanımına daha somut bir örnek aktarır: "Onun otağ1 kilise [bahar] gibidir, o da orada bir heykelciktir. Onun sarayı cennet gibidir, o da orada bir huridir.” Örnekte açıkça bahar lafzı geçmekte ve kilise anlamında kullanılmaktadır. Ayrıca eserde sözcüğün Belh’teki bir ateşgede tapınağının özel adı olduğu hatırlatılıp bu anlama Nizâmî'nin İkbâlnâme'sinden bir beyit de örnek verilir: "Belh’te iç yakıcı bir ateşgede [bahar] vardı. Onun yüzünden kırmızı gülün keyfi kaçmıştı." (Şu'ûrî Hasan Efendi, 2019, ss.744-745)

Hem çağdaş hem klâsik kaynaklarda yer alan Belh’teki bu tapınağın, klâsik Türk şiirinde bahar sözcüğü etrafında birçok çağrışıma imkân sağladığı söylenebilir. Ferheng-i Şu'ûrî'de sözcüğün tapınak anlamına dair verilen Farsça şiir örnekleri de göstermektedir ki bahar sözcüğü ile ilgili klâsik Türk şiirinde yer alan kilise yahut tapınak vurgusu, sade bir benzetme unsuru değil anlam çağrışımı yoluyla sözcüğün literatürde de bilinen ve kullanımda olan anlamına çekilen önemli bir dikkattir. Bu yönüyle bahar lafzının, sözcüğün tapınak/kilise anlamını hatırlatacak bir çağrışımla kullanıldığ ve onun adeta mazmunlaştı̆̆ $1^{5}$ söylenebilir.

Steingass'in Farsça-İngilizce sözlüğü, "bahâr" maddesinde sözcüğün diğer birçok anlamı ile birlikte Budist tapınağı (a Buddhist temple) ve put (an idol) anlamlarına da sahip olduğunu kaydeder. Yine bir mekânın adı olduğu bilgisi de "Merv yakınında bir köy ismi" kaydıyla yer alır (Steingass, 1998, s.209).

Burhan-1 Katı'da "behâr" maddesinde sözcüğün dokuz manaya sahip olduğu belirtilir ve mevsim, çiçek gibi anlamlarının yanında bir cezirenin de ismi olduğu hatırlatılır. Bunlara ek olarak Çin

${ }^{4}$ Deyr-i dil böyle sanem-hâne-i Ferhâr olmak

Hep senüy ey büt-i nâzende hayâlindendür

Nedîm (g. 21/3)

Tamâm gösterür itdükçe nâz ile cilve

Usûl-i tarz-1 bütân-1 tırâz-1 Ferhâr'1

Nef'î (k. 45/2)

Gubârı ol kadar hos bû ki andurmaz dem-i subha

Abîr-i ceyb-i gîsû-yı bütân-1 Çîn ü Ferhâr'1

Nef'î $($ k. 13/20)

5 "Mazmundan beklenen, edebî eserin, özellikle şiirin beyitleri arasına ustaca gizlenmiş ince anlam, zarif söz hatta belli belirsiz bir sezdirme"dir (Mengi, 2010, s.60). 
ikliminde bir put hanenin adı olduğu, Türkistan'da bir ateşgede için kullanılmakla birlikte, heykel ve altın işlemeli nakışlarla süslü eve denildiği gibi put/sanem anlamlarına da geldiğine dikkat çekilir. "Behâr-hâne"nin de yine put hane manasında olduğu kaydedilir. Sözlüğün "Nev-behâr" maddesinde ise Belh şehrinde meşhur Bermekî sülalesinin inşa ettirdiği bir ateşgedenin ismi olduğu bilgisi kayıtlıdır (Mütercim Âsım Efendi, 2009s.58). Starr'ın da üzerinde durduğu Kabil'de yer alan Subahar isimli oldukça gösterişli bir manastırdan (Starr, 2019, s. 138) Burhan-1 Katı'da "Sûbehâr" adıyla "bir kadim put hane adı" olduğu ve "Gaznin nevahisinde" bulunduğu şeklinde bahsedilir (Mütercim Âsım Efendi, 2009, s.692). İki farklı bölgede yer alan tapınağın bahar kökünden geldiği anlaşılan lafızlarla karşılanması, sözcüğün tapınak anlamının yaygın olduğunu göstermektedir.

Sözlüklerde bahar kelimesinin tapınak anlamında kullanıldığına dair birçok örneğin varlığı ile birlikte Orta Asya araştırmacıları da baharın tapınak karşılığında kullanıldığına işaret ederler (Starr, 2019, s.175; Barthold, 2015, s.7). Sözcükte mündemiç olan görsel bir imaj ve mekân metaforu niteliği şehir planlamasında da kendisini göstermektedir. Nev-bahâr isimli tapınak sadece edebiyatta etkisini göstermemiş, şehir ve mimarîde tasarım ve formları da belirlemiştir. Budizm'in Orta Asya'daki en önemli merkezlerinden olan Belh'teki Nevbahar isimli Budist manastır, daire formunda genişleyen bir plana sahiptir. Öyle ki İslam şehir tarihinde ne önce ne de sonra pek bir örneği olmayan merkezi bir planla inşa edilmiş ilk şehir olma özelliğini barındıran Bağdat'ın da daire şeklinde bir planla inşa edilmesinde bu manastır formunun etkisi olduğu belirtilmektedir (Starr, 2019, ss.190-191).

Şiirdeki bahar sözcüğünün görsel bir imaja dönüşmesi ile tasvir ve süslemeleriyle birlikte doğal bir güzelliğe de sahip Belh'teki bu tarihi tapınak arasında bir ilgi olduğu anlaşılmaktadır. Budistlerin mabedi olan ve her sene Nevruz günlerinde ayrıca bayram kutlamalarına da ev sahipliği yapan "Nev-bahâr", söz konusu şehri çok önemli kılarken Amuderya da bu şehre ayrı bir güzellik katmıştır. Belh deresi, şehre hayat bahşetmekte ve şehri bağlik ve çiçeklik şeklinde bir bahçe kılmaktadır. İslam kaynaklarında görkemli, muhteşem anlamına gelen "behiyye" (elBelhü'l-behiyye) sıfatıyla anılan Belh’in, İslâm fethinden bir süre önce Nev-bahâr adlı mabedi ile Budistlerin ziyaretgâhlarından biri olduğu gibi Zerdüştîler için de önemli olduğu bilinmektedir. Bu bölgede yer alan ve dönemin en önemli Budist eğitim merkezi olan söz konusu mabet "Nava Vihara"6 olarak da bilinmektedir. İslam seferleri sırasında yıkılan ve İslâm müelliflerinin "Nevbahâr" adıyla andıkları viharanın kalıntılarının ise bugün Top-1 Rüstem ve Taht-1 Rüstem isimleri verilen harabelerin bulunduğu bölgede yer aldığı sanılmaktadır (Furkani, 2016, s.330; Esin, 1972, ss.29-31; Yazıc1, 1992; Erşan ve Akdeniz, 2019, s.104).

Bahar sözcüğüyle köken ilişkisi olduğu kabul edilen viharalar7 (manastır), ilk olarak eğitim ve konaklama amaçlı olarak ticaret yollarının yakınında, yüksek arazilerde kayalara oyularak yapılmıştır. İlk Budist vihara8ları olarak bilinen bu mağaralarda, M.S.IV ve VI. yüzyıllarda yapılmış resimler bulunmaktadır (Erşan ve Akdeniz, 2019, ss.94-95). Erken dönem örneklerinde de görülen duvar süsleme ve resimleri, sözcüğün görsel bir imaj1 ifade etmek için tercih edilmesinde etkili olmuştur denebilir.

\footnotetext{
${ }^{6} \mathrm{Bu}$ kompleksin önceleri, "New-wihara" olarak bilinen en büyük Zerdüşt mabedi olduğu ve daha sonra şehre Budizm’in hâkim olmasıyla Budist mabedine dönüştürüldüğü de kayıtlarda yer alır (Demirci, 2014, s.77).

7 Mâverâünnehir'de tarihî bir şehir olan Buhara'nın da "vihara"dan türemiș bir isim olduğu kabul edilir (Şeşen, 1992).

${ }^{8}$ Sanskritçede konut veya ev anlamına gelen sözcük, eski Hint döneminde Budist manastırlar için kullanılmaktadır. Önceleri viharalar yağmur mevsimi boyunca gezgin keşişlerin barınak olarak kullandığı yerlerdi; ancak sonra varlıklı Budistlerin bağışlarıyla Budist mimari kimliği kazanarak eğitim merkezlerine dönüşmüştür (https://www.newworldencyclopedia.org/ entry/Vihara).
} 


\subsection{Klâsik Türk Şiirinde Görsel Bir İmaj ve Mekân Metaforu Olarak Bahâr}

Tapınakların 1ş1tılı ve çok renkli heykel ve tasvirlerle dolu olması, yine klâsik dönem şiirinde sevgilinin görsel güzelliğine vurgu yapılacağı zaman putla benzeştirilmesi, bahar sözcüğünün tapınak/kilise anlamı üzerinde durmayı bir zaruret haline getirmektedir ${ }^{9}$. Bu çerçevede görüngünün, aldatıcı güzelliğin put olarak tasviri ve sevgilinin büyüleyici güzelliğini bahar tasvirleriyle dile getirme ile tapınak, manastır ve kiliselere bahar denilmesi arasında bir ilgi olduğu söylenebilir. Bu yüzden klâsik Türk şiiri geleneğinde sevgilinin özellikle görsel imajlarla tasviri ve methi ayrıca onun teshir eden aldatıcı güzelliği söz konusu olunca bir put olarak kabul gören varlığı baharın tapınak, manastır ve kilise anlamlarıyla birlikte düşünülmelidir.

Şeyhî saf gönlünün put kadar alımlı sevgilinin renk ve süsleriyle aldandığını, bu yüzden resim ve tasvirden gözünü alamadığını, ona bakakaldığını ifade eder. Gelibolulu Âlî ve Tâcî-zâde Ca'fer Çelebi de baharın göz alıcı renkleri ortaya çıkarması nedeniyle aldatıcı niteliğini vurgulamaktadır:

Ben sâde-dile reng ile nakş oynadı bir büt

Bu nakş u nigâra gözüm andan nigerândur

Şeyhî (g. LXVIII/7)

Berd-i 'acûzuy ayla cevân-merd mekrini

Aldanma nev-bahâra sanup anı bir nigâr

Gelibolulu Âlî (g. 227/2)

İgen bu nakş-1 nigâr-1 bahâra aldanma

Ki pâyidâr degüldür muzahferât-1 cihân

Tâcî-zâde Ca'fer Çelebi (k. 26/26)

Şiirlerde görsel bir imaj öne çıkarılmak istendiğinde kilisenin (deyr) sahip olduğu resim ve süslemeler sebebiyle bir istiare olarak dış mekânın ifadesinde kullanıldığı görülmektedir. Nâłilî-i Kadîm de dış mekân olarak dünyanın sahip olduğu görsel güzellikleri kilise metaforu üzerinden tasvir eder ve sessizliğinin onun bir faili olmadığı anlamına gelmediğini aksine Allah's kast ederek bir ressam kaleminden çıkan tasvir ve süslemeler olduğunu ifade eder:

Hâmûş görüp Nâ'iliyâ sayma bu deyrün

Nakş-1 suver-i hâme-i ressâmı tehîdür

Nâ'ilîi-i Kadîm (g. 90/7)

Neşâtî baharda her lalenin bir micmer yaktığını ifade ederek kiliselerde buhurdan (micmer) yakma âdetiyle "bahâr"ın kilise anlamını çağrıștırmaktadır:

Bahârdur yine her lâle yakdı bir micmer

N'ola nisâr-1 gülâb itse ebr-i nisânî

Neşâtî (k. 11/2)

Birçok araştırmacının, doğuşundan itibaren put ve putçuluğa karşı çıkan İslam kültürü içinde yer alan bir edebi anlayışta put kavramının bu kadar sık kullanımının ortaya çıkardığı netameler üzerinde durduğu bilinmektedir. Annemarie Schimmel de bu netameye dikkat çeken araştırmacılardandır. Schimmel'in, bu çelişkiyi tasavvufun mecazi aşktan hakiki aşka giden mecaz ilişkisiyle açıklamaya çalıştı̆̆ bununla birlikte bunun birçok yanlış anlamalara da neden olduğunu ifade ettiği görülür: "Put kavramı (Arapçada sanem, Farsçada büt) bütün İran, Türk ve

Her bir sanemün baksạ tasvîri derûnumda

Yoksa bu benüm sînem büt-hâne midür cânâ

Gelibolulu Âlî (g. 20/2)

[Her bir putun tasviri içimdedir; yoksa bu benim gönlüm bir put hane midir, ey sevgili?] 
Hint-İslam edebiyatına nüfuz etmiştir; Maşuka genellikle büt denilir. Böylece katı tektanrıcı bir din ile 'putlar'ın edebî bir sanat olarak kullanımı arasındaki kafa karıştırıcı gerilim Fars dünyasının edebiyat tarihinde gözlenebilir. Bu açıdan mutasavvıflar, Allah insanı 'Kendi suretine göre' yarattığı için, Tanrı'yı insan 'putlar' aracılığıyla görmekle mutlak aşk nesnesine ulaşmanın bir yolunun bulunabileceğini ileri sürmüşlerdir; her şeyden önce 'eğretileme, hakikate giden köprüdür.' Fakat 'putlar'ın sürekli olarak metinlerde görülmesi yalnızca zâhiri kelamcılarda değil, Müslüman olmayan okuyucularda da bu tarz edebiyata ilişkin pek çok yanlış anlamanın doğmasina neden olmuştur." (Schimmel, 2004, ss.61-62)

Sevgilinin bir put olarak tavsifi ile bahar sözcüğünde mündemiç olan tapınak anlamının mekân kaynaklı metaforik kullanımının anlaşılması bu çelişkiyi izale edebilir. Şiirlerdeki put ögesinin yaygın varlığı, sevgilinin görsel güzelliğini metaforik olarak ifade arayışıyla ilgilidir. "Bahar"1n tabiattaki görsel güzelliğin doruğa ulaştığı bir zaman dilimini karşılamakla birlikte resim ve nakış gibi tezyini ögelerin ve heykellerin bulunduğu göz alıcı bir mekânın da adı olması, bu metaforik ilgiyi kolaylaştırmaktadır. Put ve bahar kavramları ortak bir mekân metaforuna dayandığından sevgili bir put olarak çağrılırken ona dair güzellik unsurlarının da tabiatın baharda kazandığı güzelliklerden seçilmesi, sözcüğün tapınak/kilise anlamıyla bir bütünlük arz etmektedir. Bu kullanımda pagan bir dini unsurun kültürel etkisinden ziyade görsel imajı renkli ve canlı bir tonda ifade arayışının hâkimiyeti söz konusudur.

Şairler de put ve put hane kavramlarının oluşturduğu netamenin farkında olarak inanan bir Müslüman'ın put haneyi mevzu edinmesinin çelişkilerini ifade ederler:

Dil deyrini tasvîrün ile zînet idermiş

'Âlî gibi mü'min kişi büt-hânede n'eyler

Gelibolulu Âlî (g. 428/5)

Şiirlerde, tapınak/kilise anlamı hatırlatılacak biçimde bahar, mekân tasvirleriyle birlikte kullanılmıştır. Bahçenin sahip olduğu bütün renk ve göz alıcılığıyla duvarları suret ve nakışlarla süslü, muhtelif yerlerinde canlı denebilecek kadar etkileyici şekilde yontulmuş ve renklendirilmiş çeşitli heykellerin bulunduğu bir tapınak yahut kilise olarak tahayyül edildiği görülmektedir. Şairi bu hayale sürükleyen faktörün sadece görsel bir imajın etkili bir benzetme yahut istiare yoluyla tasviri olduğu düşünülmemelidir. Birçok örnek kaynakta görülebileceği üzere bahar/nev-bahar sözcüğünün, gerçekte bilinen bir mekânın, resim ve heykelleriyle meşhur bir tapınağın adı olmasının da bunda etkili olduğu unutulmamalıdır. Şair, böylece aradığı anlam yoğunluğu ve çağrışım zenginliği hedefine ulaşmakla birlikte sözünü bir mesnede dayayarak ona edebî bir meşruiyet de sağlamaktadır.

Terk eyle zühdi mezheb-i rindân-1 'aşka gir

Nakd-i revânı bir büt-i zîbâ-cemâle vir

Bir kaç piyâle bâde çeküp deyr-i bâğa ir

Bülbül kitâbın almış ele pendi bu ki dir

Hoşdur piyâle bir sanem-i gül-'izâr ile

Bâkî (mus.6/III)

Bâki bahçeyi kiliseye benzeterek (deyr-i bâğ) bahar sözcüğünü kullanmadan onun kilise/tapınak anlamına işaretle baharda bağ bahçenin canlanması, 1ş1ltılı ve rengârenk bir görünüme sahip olması arasında ilgi kurmaktadır. Bu ilgi sayesinde şirde baharın lafzen telaffuz edilmemesi ve onun bir işaretle çağrıştırılması mazmun olarak kullanımını akla getirmektedir. Benzer bir mazmun temayülünü şairin "Gül-sitân oldı bu gün bir sanem-i lâle-'izâr” (gülbahçesi, lale yanaklı bir puta dönüştü bugün) misrainda da görmek mümkündür. Gül bahçesi, bahar mevsimi ve put 
birbirini tahattur ettiren çağrışım geçişliliği sağlamakta bahara lafzen yer verilmeyerek de bir mazmun gibi sözcük çağrışım yoluyla hatırlatılmaktadır.

Pîrehen berg-i semen gûy-1 girîbân şeb-nem

Gül-sitân oldı bugün bir sanem-i lâle-'izâr

Bâkî (k. 18/14)

Şiirlerde, baharda dünya göz alıcı renkliliğe sahip olduğu için onu put hanelere (oralarda da göz alıcı tasvir ve heykeller bulunmakta) benzetmek kolay olmuş olmalıdır. Aşağıdaki beyitte bahar, nigar ve Mani birlikte zikredilerek Mani'nin pagan dinine de gönderme yapılmıştır. Beyit, bahar kavramını nakkaş Mani ile birlikte düşünmemizi sağlayan ipuçları içermektedir. İpuçlarını birleştirmek için meşhur bir nakkaş olan Mani'nin Erjeng veya Nigâr/Nigâr-hâne de denilen görenleri büyüleyen resim mecmuasının sahibi olduğu ve onunla kendisine mürit devşirdiği hatırlanmalıdır (Pala, 1998,s.128):

\section{Bülbülde savt-1 rengîn güllerde sûret-i Çîn}

Fasl-1 bahâr Mânî gülşen Nigâr-hâne

Bâkî (g. 470/3)

Bahar sözcüğünün kilise anlamı, şiirlerde çeşitli anlam ilgileriyle de sezdirilmektedir. Beyitlerde her ne kadar Hz. İsa'nın ölüleri diriltme mucizesine telmihle baharın bitkilere tazelik bahşetmesi arasında ilişki kurulsa da kiliseye bahar denmesinin de bu anlam ilgisinde etkili olduğu söylenebilir. Nev'̂̀nin "Hava İsa nefesli, bağ put hane şeklinde(dir); sünbül başına gök renkli (mavi) tülbent sarındı.” anlamındaki aşağıdaki beytinde lafzen bahar geçmemekle birlikte sözcüğün tapınak/kilise anlamını hatırlatacak biçimde bir bahar tasviri açıkça göze çarpmaktadır. Baharın müstakil olarak da put hane anlamında kullanıldığı bilinmektedir. Şairin bağı bir put hane olarak algılamasında baharın putperestlik tapınağı olarak bilinmesiyle doğrudan ilgisi bulunmaktadır. Hz. İsa'nın nefesiyle (Mesîh-nefes) ölüleri diriltme mucizesine telmih, Hz. İsa'dan dolayı adı geçmemekle birlikte akla kiliseyi getirmektedir. Şairler bir çağrışım zenginliği sağlamak adına sözcüğün kilise/tapınak anlamını hatırlatmak için bahar ve $\mathrm{Hz}$ İsa/Mesîh kelimelerini bir arada böylece kolaylıkla kullanmış olmalıdır. Zâtî de bu meyanda kışın bitkilerin varlığını yok etmesine karşılık baharın İsa nefesi gibi onlara yeniden varlık kazandırdığını vurgular:

\section{Hevâ Mesîh-nefes bâğ şekl-i büthâne \\ Sarındı başına sünbül kebûd dülbendi \\ Nev'î (g. 519/3)}

Şitâ vücûd-1 nebâtâtı eylemişdi ‘âdem

Yine vücûda getürdi bahâr-1 İsâ-dem

Zâtî (k. 13/1)

Bahar'ın bir mekân metaforu olarak varlığı, şiirlerde mekân süslemelerine ait ögeleri öne çıkarmaktadır. Nef'î baharı bir nakkaş olarak tasvir ederken tıpkı tapınaktaki göz alıcı nakış ve süslemelerin görenleri meftun etmesi gibi baharın da aklı meftun ettiğini nazarın ise kendisinden yardım istenen Yaratıcı'nın sanat eserlerine hayran kaldığını ifade eder:

Hired meftûn olur nakş-1 bahâr-1 revnak-1 bâğa

Nazar hayrân kalır âsâr-1 sun'-1 müsteân üzre

Nef'î (k. 5/6)

Şiirlerde nakış, resim ve put anlamlarında kullanılan "nigâr" sözcüğünün baharla birlikte kullanımı, sözcüğün sahip olduğu tapınak anlamını öne çıkarmaktadır. Lügatte nigar için "Hûb- 
rû ve mahbûbân ki put (büt) ve mug manasıyla müteradiftir. Hûb-rûlara 1tlak olunur. Büthâneye, mugistân dedikleri gibi nigâristân dahi derler. Bir anlamı da nakıştır.” (Şu'ûrî Hasan Efendi, 2019, s.3546) açıklaması yapılır. Metin tanıklığına başvurulduğunda, bütün bu anlam ilgilerinin "bahâr" ve "nigâr" sözcüklerini birbirine yaklaştırdığı anlaşılmaktadır. Aşağıdaki beyitte sevgilinin güzelliğinin bahar ve bağı aratmayacağı ifade edilmekle birlikte "bahâr", "bâğ", "nigâr" ve "cinân"ın (cennetler) birlikte kullanımı da bir tenasüp oluşturmuştur:

Bahâr u bâğ ise maksûd hüsn-i yâri görün

Garaz cinân ise kûy-1 nigâra varı görüy

Bâkî (g. 257/1)

Yine Bâkî’ye ait aşağıdaki beyitte "bâğ", "bahâr", "nakş" ve "nigâr" gibi görsel bir tasviri ifade eden sözcüklerin oluşturduğu imajın, duvarlarında fresk ve ikonların bulunduğu (nakş), zemininde heykellerin (nigâr) durduğu bir tapınak/kilise tasvirine dayandığ1 anlaşılmaktadır:

Bâğ pür-nakş u nigâr oldı bahârı severin

Mâ'ilem nakşına gayet de nigârı severin

Bâkî (g. 385/1)

Mehmed Efendi'nin beytinde "resm-i dil-ârâ" (gönül süsleyen resim), "nakş-1 nigâr" (put/sanem süslemesi), "tarh" (süslemeli desen), "nakş-bend" (süslemeli dokuma sanatkârı) ve "bahâr" gibi hepsi bir mekân tasvirine ait kavramların oluşturduğu tenasüp de yukarıda ifade edilen baharın tapınak anlamıyla öne çıkan mekân metaforu niteliğini teyit eder:

Nedür bu resm-i dil-ârâ nedür bu nakş-1 nigâr

Ki tarh itdi çemen-zâra nakş-bend-i bahâr

Mehmed Efendi (Zavotçu, 2017, s.193)

Baharın bir mekânın adı olması, onun mekânla kurduğu çağrışım ilişkisini çok güçlü kılmaktadır. Şiirlerde sık biçimde bahar, tezyini güzelliğiyle öne çıkan saraya (kasr) benzetilir. Zâtî'ye ait beyitlerde, baharın mekân metaforu yoluyla anlamını aldığı nakışlı tapınaktan mülhem olarak bahçeyi tezyin edilmiş bir kasır gibi süslediği aktarılmaktadır:

Her bâğı bahâr eyledi bir kasr-ı münakkaş
Vasfında anuy cümle zebân ‘âciz ü kâdir

Zâtî (k. 48/10)

Kasr-1 bâğı bezedi geldi Züleyhâ-yı bahâr

Yine çâk ola bigi Yûsuf-1 gül pîreheni

Zâtî (k. 61/2)

Nâ'ilî-i Kadîm, bahçeyi saraya (kasr-1 bâğ) benzeterek kader nakkaşının bahar kitabının sayfalarına yepyeni güller çizdiğini söyler. Beyitte birlikte yer alan "kasr", "bâğ", "nakkâş" ve "bahâr" sözcükleri, baharın müzeyyen bir tapınağı karşıladığı bilindiğinden bir tenasüp ilgisi oluşturmaktadır:

Nakkâş-1 kâr-gâh-1 kader kasr-1 bâğda

Yazdukça nev-be-nev safahât-1 bahâra gül

Nâ'ilî-i Kadîm (müz. 230/14)

Aşağıdaki beyitlerde Nedîm'e "nev-bahâr"1 kasr suretinde hayal ettiren faktör de sözcüğün anlam evreninde mevcut olan bir mekânın adı olma niteliğidir. "Nev-bahâr"ın müzeyyen bir tapınağın özel adı olması metafor olarak mekân çağrışımını kolaylıkla sağlamaktadır: 


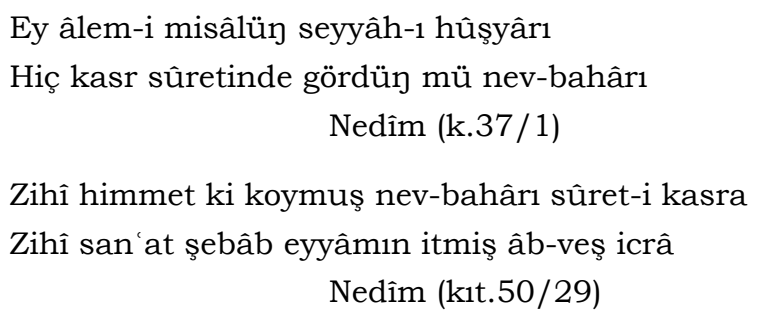

Baharın mekân metaforu olarak tasvirle ilişkisi, çok güçlü bir şekilde birçok şiir örneğinde metin tanığ1 olarak görülebilir. Gelibolulu Âlî’nin aşağıdaki beytinde birer tasvir terimi olarak zeminşekil ilişkisi hatırlatılmaktadır. Tasvirde görülen altyapıya zemin denilmekte, zamanın da şekil/motif anlamında "zemin üzerindeki hareketli kısmı ifade etmek" için kullanıldığ bilinmektedir (Şahin, 2013: 295-296). Klâsik dönem şiirinde zaman ve zemin birlikte kullanılmış bahar bir ressama benzetilerek onun bir mekânın adı olma niteliği çağrıştırılmıştır. Örnekleri çok olan bu ilişkiyi Nâ'ilî-i Kadîm’in beytinde de görmek mümkündür:

Nakş-1 rengîni zemîn üzre geçer miydi zemân

Tab'-1 'Âlî gibi deprenmese ressâm-1 bahâr

Gelibolulu Âlî (g. 197/6)

'Aksi bülend ü pest bahâruy nücûm ile

Peydâ yüzinden nakş-1 zemîn ü zamân gibi

Nâ'ilî̀-i Kadîm (k. X/13)

Gelibolu Âlî de "nev-bahâr"1n maruf bir tapınak olduğu bilgisinden hareket ederek tapınaktaki hizmetlilerin giydiği özel kıyafetle baharın bahçeyi nakşetmesini ilişkilendirmektedir:

Gülşen nigâra döndi giyüp nakş-1 nev bahâr

Hidmetdedür çenâr u semenzâr u nev-bahâr

Gelibolulu Âlî (g. 200/1)

\section{SONUC}

Yaygın olarak bir mevsimi ifade etmekle birlikte kökeni, bir tapınağın özel adına dayanan bahar, klâsik Türk şiirinde güzellik imajlarına görsel kaynaklık etmiştir. Kelime yaygın olan mevsim anlamının dışında gül çeşitleri için de kullanılmaktadır. Ayrıca çiçek yapraklarına bahar denildiği gibi sözcük, bizatihi çiçek ve yüz/yanak anlamlarını da karşılar. Farsçadan dilimize geçmiş ama köken olarak Sanskritçeye dayanan "bahar"la put/sanem anlamı da kast edilmektedir. Şiirlerde sevgilinin güzelliği, bahar mevsiminde tabiatın kazandığı görünümden alınmış imajlarla ifade edilmektedir. Çiçek ve bitkilerin stilize bir formda, klâsik Türk şiirinde güzellik objesi olarak kullanılmasında bahar kavramıyla birlikte oluşan çağrışım ve anlam zenginliğinin payı olduğu anlaşılmaktadır. Şiirlerde baharın tapınak yahut kilise anlamının sık vurgulandığı, sözcüğün bu iki mekâna ait başka ögelerle birlikte kullanılmasıyla da fark edilmektedir. Kilisenin tapınaklara benzer biçimde içerisinde resim ve putlar barındırması nedeniyle olmalı ki klâsik Türk edebiyatında bahar sözcüğüyle de karşılandığı görülmektedir.

Klâsik Türk şiirinde sevgili imajının bazen bir put olarak varlığı ile bahar sözcüğünde saklı olan tapınak anlamı birbirini tamamlamaktadır. Bir güzellik imajı olarak "put"un yaygınlığının, mekân kaynaklı metaforik bir kullanıma dayandığı söylenebilir. Şiirlerde, tapınak/kilise anlamı hatırlatılacak biçimde bahar, mekân tasvirleriyle birlikte kullanılmıştır. Şiirlerde, baharda dünya göz alıcı renkliliğe sahip olduğu için onu put hanelere (oralarda da göz alıcı tasvir ve heykeller bulunmakta) benzetmek kolay olmuş olmalıdır. Klâsik Türk şiirinin disiplinler arası bir boyut 
taşıdığı bahar gibi bir mekâna özel ad olmuş sonra ondaki mekânsal çağrışımın görsel imajlara dönüşmüş olmasından da anlaşılmaktadır.

Hakem Değerlendirmesi: Diş bağımsız.

Çıkar Çatışması: Yazar çıkar çatışması bildirmemiştir.

Finansal Destek: Yazar bu çalışma için finansal destek almadığını beyan etmiştir.

Etik Onay: Bu makale, insan veya hayvanlar ile ilgili etik onay gerektiren herhangi bir araştırma içermemektedir.

Yazar Katkısı: Mustafa Uğur Karadeniz (\%100)

Peer-review: Externally peer-reviewed.

Conflict of Interest: The author declare that there is no conflict of interest.

Funding: The author received no financial support for the research, authorship and/or publication of this article.

Ethical Approval: This article does not contain any studies with human participants or animals performed by the author.

Author Contributions: Mustafa Uğur Karadeniz (100\%)

\section{KAYNAKÇA}

Akkuş, M. (2018). Nef'î dîvânt. Erişim adresi: https://ekitap.ktb.gov.tr/Eklenti/57741,nefidivanipdf.pdf?0

Aksoyak, İ., H. (2018). Gelibolulu Mustafa Âlî dîvânı. Erişim adresi: https://ekitap.ktb.gov.tr/ Eklenti/58695,gelibolulu-mustafa-ali-divanipdf.pdf?0

Barthold, W. (2015). Uluğ Beg ve Zamanı. İsmail Aka (Çev.), Ankara: Türk Tarih Kurumu Yayınları.

Biltekin, H. (2018). Şeyhî dîvânı, Erişim adresi: https://ekitap.ktb.gov.tr/Eklenti/61044,seyhidivanipdf.pdf?0

Demirci, M. (2014). Mevlâna'nın düşünce köklerine Belh üzerinden bir bakış. Nuri Şimşekler, Ali Temizel, Selman Karadağ (Ed.), Tarihi Süreçte Mevlâna ve Eserleri (s.75-92) içinde. Konya: Selçuk Üniversitesi Mevlâna Araştırmaları Enstitüsü Yayınları.

Devellioğlu, F. (2001). Osmanlıca-Türkçe ansiklopedik lûgat, Ankara: Aydın Kitabevi Yayınları.

Erşan, H. ve Akdeniz G. (2019). Türk-İslam medreseleri ve Budist viharaları üzerine bir inceleme. Kırklareli Üniversitesi Mühendislik ve Fen Bilimleri Dergisi, 5(2), 87-110. doi: 10.34186/klujes.329757

Erünsal, E. $\quad \dot{I}$. (2018). Tâcî-zâde Ca'fer Çelebi dîvânı. Erişim adresi: https://ekitap.ktb.gov.tr/Eklenti/59332,taci-zade-cafer-celebi-divanipdf.pdf?O

Esin, E. (1972). Belh, Türk Edebiyatı, 12, 29-31.

Furkani, M. (2016). Tarihte model İslam kentlerden biri olarak Belh şehri. 4. Uluslararası Kentsel ve Çevresel Sorunlar ve Politikalar Kongresi. Erişim adresi: http://aksaray.edu.tr/ files/bilgi_belge/2017/bildiri_kitabi.pdf

Güç, A. (2007). Put. TDV İslâm Ansiklopedisi. Erişim adresi: https://islamansiklopedisi.org.tr /put

İpekten, H. (2019). Nâ'ilî̀-i kadîm dîvân. Erişim adresi: https://ekitap.ktb.gov.tr/ Eklenti/67155,naili-i-kadim-divanipdf.pdf?0

Kaplan, M. (2019). Neşâtî dîvân1. Erişim adresi: https://ekitap.ktb.gov.tr/Eklenti/67330,nesatidivanipdf.pdf?0\&_tag1=006964F7A491139BEB893C13F024BA71C07840A2\&crefer=B5E A2FAD2092097904C23CDD3580BAA5E217A622A3AE8F76A3BAD9CF5AC8480B 
Kılıç, F. (2018). Âşık Çelebi-Meşâ'irü'ş-Şu'arâ. Erişim adresi: https://ekitap.ktb.gov.tr/Eklenti/ 59036,asik-celebi-mesairus-suarapdf.pdf?0

Kur'an Yolu Meali ve Tefsiri. Erişim adresi: http://kuran.diyanet.gov.tr/Tefsir/

Kurtoğlu, O. (2017). Zâtî dîvânı (gazeller dışındaki şiirler), https://ekitap.ktb.gov.tr/Eklenti/ 56164,zati-divanipdf.pdf

Küçük, S. (1994). Bâkî dîvânı. Ankara: TDK Yayınları.

Macit, M. (2017). Nedîm Dîvânt. Erişim adresi: https://ekitap.ktb.gov.tr/Eklenti/56214,nedimdivanipdf.pdf?0

Mengi, M. (2010). Divan şiiri yazıları, Ankara: Akçağ Yayınları.

Mütercim Â. E. (2009). Burhân-ı katı. Mürsel Öztürk, Derya Örs (Haz.), Ankara: TDK Yayınları.

Onay, A. T. (2009). Divan şiiri sözlüğü. Cemal Kurnaz (Haz.), İstanbul: H Yayınları.

Pala, İ. (1998). Ansiklopedik divan şiiri sözlüğü, İstanbul: Ötüken Yayınları.

Schimmel, A. (2004). Tanrı'nın yeryüzündeki işaretleri. Ekrem Demirli (Çev.), İstanbul: Kabalcı Yayınlar1.

Starr, S.F. (2019). Kayıp aydınlanma. Yusuf Selman İnanç (Çev.), İstanbul: Kronik Yayınları.

Steingass, Frank (1998). A comprehensive Persian-English dictionary. Beirut: Librairie du Liban Publishers.

Şahin, E. (2013). Bâkî Dîvânı'na Göre 16. Yüzyıl Osmanlı Toplum Yapısı. FSM İmî Araştırmalarİnsan ve Toplum Bilimleri Dergisi, 2, 285-310. Erişim adresi: https://dergipark.org.tr/en/ download/article-file/73032

Şeşen, R. (1992). Buhara. TDV İslâm ansiklopedisi. Erişim adresi: https://islamansiklopedisi. org.tr/buhara

Şu'ûrî H. E. (2019). Ferheng-i Şu'ûrî.Ozan Y1lmaz (Haz.). İstanbul: Türkiye Yazma Eserler Kurumu Başkanlığı Yayınları.

Tulum, M. veTanyeri, A. (1977). Nev'̂̀ divan. İstanbul: İstanbul Üniversitesi Edebiyat Fakültesi Yayınlar1.

Yazıc1, T. (1992). Belh. TDV İslâm ansiklopedisi. Erişim adresi: https:/ / islamansiklopedisi.org.tr/belh

Zavotçu, G. (2017). Rızâ tezkiresi. Erişim adresi: https://ekitap.ktb.gov.tr/Eklenti/60735,rizatezkiresipdf.pdf?0 


\section{SUMMARY}

The word "bahâr" (spring), which corresponds to a season in its widespread use, corresponds to the meanings of flowers, leaves, faces, and cheeks in classical Turkish poetry, as well as put, temple, and church. The quest to express a visual depiction is conspicuous in this wide variety of uses of the word. It can be said that the elements of beauty in classical Turkish poetry arise from the reflections of a space aesthetic. When we look at the equivalent of "bahâr" in the lexicon and its use in sample texts, it will be seen that the word is actually a concept expressing the place, but gradually transformed into another semantic form that shows similar features to the qualities of that place. It can be said that the presence of pictures and idols in churches as in temples caused these places to be expressed with the word spring in classical Turkish literature. When a visual image is desired to be highlighted in poems, it is seen that the church (deyr) is used as a metaphor for the expression of the outer space due to the pictures and decorations it has. In the poems, the word spring is used together with the depictions of the place in a way to remind the meaning of the temple / church. The garden is depicted as a temple or a church, the walls of which have striking colours, decorated with figures and embroideries, with various sculptures carved and coloured so vividly in various places. It is known that the special name of a very spectacular temple in Balkh as it is mentioned in many sources is "Bahar / Nev-Bahar". It can be said that this temple, which has various paintings on its walls and many idols in various places, provides an opportunity for connotations with the word "bahâr" in classical Turkish poetry. "Vihara", from which the word spring is derived from itself, is both an accommodation and education centre for Buddhist monks. It can be said that the fact that spring (bahâr) is the name of the resurrection period after the winter season, which is a period that expresses the death of nature, reinforces this visual image. Paradise is portrayed as a springtime garden. In poems, spring reflects the memory of the longed-for heaven, constantly. The source of visual beauty images in classical Turkish poetry is the garden. A visual depiction of the lover is always tried to be made with the elements selected from the garden. The temples are full of sparkly and multicoloured statues and depictions. In classical period poetry, when the visual beauty of the lover is emphasized, it is seen that he is expressed as an idol. This must be directly related to the temple meaning of the word spring. In the poems, the world is shown as a place with an eye-catching colour in the spring season. Therefore, it would not be wrong to explain the existence of the temple metaphor in the poems with the presence of eye-catching depictions and statues in temples. Therefore, when poets emphasize visual beauty, they can easily use a concept such as an idol that is not tolerated in Islamic culture in their poems. Understanding the presence of the beloved as an idol in poems and the metaphorical use of the word temple in the word spring can eliminate this contradiction. Poets are also aware that it is dangerous to use the concepts of idol and temple as a positive image in poetry. In the semantic world of poetry, these words exist as a result of an effort to express a visual image with a beautiful description, rather than being the praise of a pagan religion. This situation justifies their use in poetry. Bahâr's existence as a space metaphor has been determinant in the visual aesthetics in classical Turkish poetry. Therefore, decorative elements belonging to a place come to the fore in poems. The fact that Bahâr is a special name for a space increases the number of aesthetic associations it establishes with space and creates a space-cantered vocabulary in poetry. The strong relationship the word establishes with space provides ease of association for poets as well. In the poems, the spring, the palace that stands out with its easily decorated beauty, etc. It is seen that they are compared to structures. In a "tenasüp" (using words related to each other together) using concepts and terms related to visual arts together with the word spring also shows that the word expresses a visual image. 